\title{
Textural evidence for high-grade ignimbrites formed by low-explosivity eruptions, Paraná Magmatic Province, southern Brazil
}

\author{
Ana Carolina F. Luchetti ${ }^{\text {a,* }}$, Darren M. Gravley ${ }^{\mathrm{b}}$, Guilherme A.R. Gualda ${ }^{\mathrm{c}}$, Antonio J.R. Nardy ${ }^{\mathrm{a}}$ \\ a Instituto de Geociências e Ciências Exatas, Universidade Estadual Paulista, Rio Claro, SP 13506-900, Brazil \\ b Department of Geology, University of Canterbury, Christchurch 8041, New Zealand \\ c Earth \&' Environmental Sciences, Vanderbilt University, Nashville, TN 37235-1805, USA
}

\section{A R T I C L E I N F O}

\section{Article history:}

Received 15 September 2016

Received in revised form 4 April 2017

Accepted 21 April 2017

Available online 22 April 2017

\section{Keywords:}

Paraná-Etendeka Province

Chapecó rocks

Palmas rocks

Silicic volcanism

High-grade ignimbrites

\begin{abstract}
A B S T R A C T
The Paraná-Etendeka Province is a Lower Cretaceous huge bimodal tholeiitic volcanic province $\left(1 \mathrm{million} \cdot \mathrm{km}^{3}\right)$ that predated the Gondwana breakup. Its silicic portion makes up a total volume of at least $20,000 \mathrm{~km}^{3}$ and in southern Brazil it comprises the Chapecó porphyritic high-Ti trachydacites-dacites and the Palmas microporphyritic-aphyric low-Ti dacites-rhyolites. The widespread silicic sheets are debated in the literature because they bear similarities between lavas and high grade ignimbrites. Here we provide new observations and interpretations for flow units with large, dark, and vesicle-poor lens-shaped blobs surrounded by a light-colored matrix. The textural features (macro- to micro-scale) of these blobs are different from typical pumice and/or fiamme and support a low explosivity pyroclastic origin, possibly low-column fountain eruptions with discharge rates high enough to produce laterally extensive high-grade ignimbrites. Such an interpretation, combined with a conspicuous absence of lithic fragments in the deposits, is aligned with a lack of identified calderas in the ParanáEtendeka Province. Maximum timescales of crystallization associated with the juvenile blobs and estimated from CSD slopes are on the order of millennia for phenocryst populations and on the order of decades for microphenocryst populations.
\end{abstract}

(c) 2017 Elsevier B.V. All rights reserved.

\section{Introduction}

The Paraná-Etendeka volcanic province of southern Brazil and western Africa is renowned for, among other things, some of the most voluminous and extensive silicic deposits recognized in the geologic record (e.g. Bryan et al., 2010). Understanding the eruptive styles and properly characterizing the mode of emplacement of these deposits is of critical importance, yet there remains a debate with proponents for a lava origin (Garland et al., 1995; Waichel et al., 2012; Lima et al., 2012; Polo and Janasi, 2014) and those that support a pyroclastic origin (Milner, 1986; Whittingham, 1989; Milner et al., 1992; Ewart et al., 1998; Bryan et al., 2010).

The recognition of structures and textures in these volcanic deposits is essential for interpreting their mode of emplacement and determining the magnitude of individual eruptions. However, for many examples of similar deposits such observable features are ambiguous, and this has led to controversy in the literature over their origin (e.g. Wolff and Wright, 1981; Bonnichsen, 1982; Bonnichsen and Kauffman, 1987; Ekren et al., 1984; Henry et al., 1988, 1990; Henry and Wolff, 1992; Branney et al., 1992; Branney and Kokelaar, 1992; Freundt, 1998;

\footnotetext{
* Corresponding author.

E-mail address: caroluch@rc.unesp.br (A.C.F. Luchetti).
}

Andrews et al., 2008; Andrews and Branney, 2011). For instance the unusual low aspect-ratios shown by some silicic lava flows (e.g. Bonnichsen and Kaufman, 1987; Henry et al., 1990; Green and Fitz, 1993 ) or the low preservation or absence of vitroclastic textures in high-grade to extremely high-grade ignimbrites (e.g. Branney et al., 1992; Branney and Kokelaar, 1992; Branney et al., 2008) due to very high eruptions temperatures $\left(\sim 900\right.$ to $\geq 1000{ }^{\circ} \mathrm{C}$ - Henry and Wolf, 1992 ) or magma composition (peralkaline rheomorphic ignimbrites in Gran Canaria and Pantelleria - Schmincke, 1969; Mahood and Hildreth, 1986, respectively) make interpretation of the mode of eruption and emplacement difficult. Nevertheless, a combination of features has been proposed to distinguish extensive silicic lavas from highgrade, lava-like ignimbrites, and vice-versa. Lavas are typically characterized by widespread, clast-supported autobreccias on their margins and base, as well as abrupt, thick, stubby lobate terminations with thick talus aprons. In contrast, high-grade ignimbrites show sharp basal contacts with the substrate, typically lack basal breccia, and are characterized by a more gradual decrease in thickness away from their source (Bonnichsen and Kauffman, 1987; Henry and Wolff, 1992; Andrews et al., 2008).

The extensive sheet-like flows, up to hundreds of kilometers long, in the Paraná-Etendeka Province (Milner, 1986; Whittingham, 1989; Milner et al., 1992; Bryan et al., 2010; Garland et al., 1995; Waichel et 
al., 2012; Lima et al., 2012; Polo and Janasi, 2014) are no exception to the lava vs. ignimbrite debate. Rare pyroclastic features, such as fiamme and globule- and cuspate-shaped shards and local basal breccias in the Etendeka led to the interpretation of these large units as high-grade ignimbrites (Milner, 1986; Milner et al., 1992). However, in Brazil, the absence of vitroclastic textures in similar deposits has led to a preferred interpretation as lavas and domes (Garland et al., 1995; Waichel et al., 2012; Lima et al., 2012; Polo and Janasi, 2014).

Here, we describe dark, lens-shaped blobs that are surrounded by a lighter-colored matrix, frequently seen in outcrops from silicic units of the Paraná Magmatic Province (PMP), southern Brazil. We characterize textures in detail and in a variety of scales, from the outcrop to the microscopic scale. We discuss their origin and suggest an alternative model of eruption and deposition for these units. We also derive crystal size distributions that provide insight into the timescales of crystallization of the magmas that gave rise to these units.

\section{Geological setting}

The Paraná Magmatic Province (PMP) includes most of the volcanic deposits of a giant bimodal tholeiitic volcanic province $\left(\sim 800,000 \mathrm{~km}^{3}\right)$ formed during the Lower Cretaceous, which preceded the breakup of
Gondwana. Correlative deposits are found in Namibia (Etendeka basin) and Angola (Kwanza and Namibe basins) in the African continent (Milner et al., 1995; Ewart et al., 1998; Marsh et al., 2001; Alberti et al., 1992; Bryan et al., 2010).

In Brazil, the PMP Volcanics were emplaced in the Paraná Basin (Fig. 1), on aeolian sandstones of the Botucatu Formation, over a period of $3 \mathrm{Ma}$ (133.6 to 131.5 Ma for the northern sector; 134.6 to $134.1 \mathrm{Ma}$ for the south $-{ }^{40} \mathrm{Ar} /{ }^{39} \mathrm{Ar}$ dating: Renne et al., 1992, 1996a, b; Turner et al., 1994; Ernesto et al., 1999; Mincato et al., 2003; Thiede and Vasconcelos, 2010; Pinto et al., 2010-134.3 $\pm 0.8 \mathrm{Ma}-\mathrm{U} / \mathrm{Pb}$ ratios from baddeleyite/zircon: Janasi et al., 2011).

Tholeiitic basalts and andesite-basalts make up 97\% of all the erupted material, while only $~ 3 \%$ of the erupted material is of silicic composition. These silicic volcanic rocks lie on top of the volcanic sequence and are grouped into two main types (Fig. 1): (1) Chapecó (ATC), composed of porphyritic high-Ti trachydacites-dacites; and (2) Palmas (ATP), comprising characteristically microporphyritic to -aphyric low-Ti dacites-rhyolites (Bellieni et al., 1984, 1986; Piccirillo and Melfi, 1988; Luchetti et al., this issue). Notably, explosively formed-collapse caldera volcanoes have not been documented in the PMP (one has been identified in Etendeka; Ewart et al., 1998), which help explain the debate as to whether the ATC and ATP include

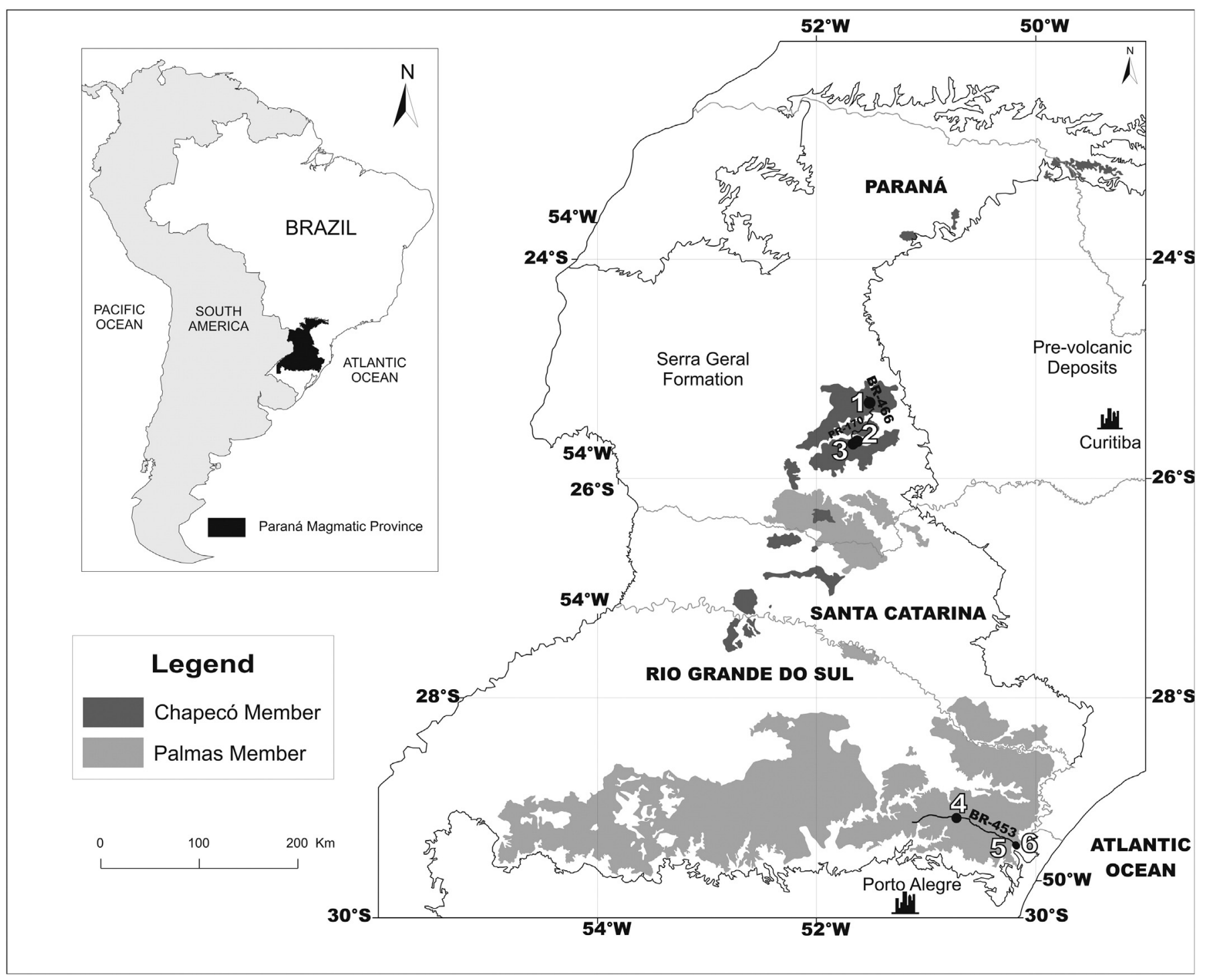

Fig. 1. Paraná Magmatic Province location and geological map with ATC and ATP rocks and respective outcrop locations (1 through 6) cited in this study. 
ignimbrites in their respective successions. Despite this, the extensive nature of silicic flows and, in particular, the observation of conspicuous and large lens-shaped blobs in most outcrops necessitates investigation and an enquiry into a possible ignimbrite-forming mechanism unrelated to caldera formation.

Some of these units have shown to be thick and quite extensive (tens to hundreds of $\mathrm{km}$ ), and its massive/coherent aspect in outcrops coupled with the apparent scarcity of pyroclastic features (i.e. glass shards, fiamme, broken phenocrysts and lithics) have led to controversy concerning their emplacement mode (e.g. Whittingham, 1989; Milner et al., 1992; Garland et al., 1995; Waichel et al., 2012; Luchetti et al., this issue). Nevertheless, they also commonly display a conspicuous 'eutaxitic-parataxitic'-like texture, which is the focus of this investigation.

\section{Methods}

We characterize in detail large lens-shaped features found in numerous outcrops in the PMP. We concentrated our efforts in some 'key' outcrops in which these features are best exposed (see location in Fig. 1), but similar features can be observed elsewhere in the province.

Field characterization included documentation of sizes and shapes of dark, lens-shaped features (hereafter referred to as blobs) that contrast with surrounding lighter material (matrix). Additionally, we documented rock textures along fractures, which can sometimes be common and which include material similar to the matrix. We sampled and studied in detail blobs and surrounding matrix from three outcrops, one from the Chapecó (outcrop 1) and two from Palmas (outcrops 4-5) silicic subunits (see Fig. 1).

We prepared polished thin sections of blobs and matrix for more detailed work. They were studied under the petrographic microscope, followed by detailed characterization carried out using scanning electron microscopy (SEM) and electron-probe microanalysis (EPMA). We used a JEOL JSM-6010 LA SEM installed at UNESP (Rio Claro, Brazil) and a Tescan VEGA3 variable-pressure SEM installed at Vanderbilt University (Nashville, USA). Both instruments are equipped with Oxford Instruments Energy Dispersive Spectrometers (EDS), used for compositional analysis and mapping. The JEOL 8230 Superprobe installed at UNESP was used in this study to obtain X-ray compositional maps. Electron Backscatter Diffraction (EBSD) maps were obtained using an Oxford AZtecEnergy Advanced Microanalysis System attached to the Tescan SEM installed at Vanderbilt, which includes integrated EDS and EBSD systems.

To attain the level of polishing needed for EBSD, thin sections with microprobe-quality polishing were subjected to a final polishing stage, of at least three-hours, using a Buehler VibroMet 2 Vibratory Polisher installed at Vanderbilt University. No conductive coating was applied on the samples, and a low $\mathrm{N}_{2}$ pressure $(<50 \mathrm{~Pa})$ was used in the SEM chamber to neutralize the surface of the sample. The settings used in the Tescan SEM for EBSD work were $\sim 10 \mathrm{~mm}$ of working distance, $70^{\circ}$ sample tilt, $20 \mathrm{kV}$ accelerating voltage, and $\sim 4 \mathrm{nA}$ beam current. Images were processed using the HKL CHANNEL5 Tango software from Oxford Instruments. We obtained EBSD maps for almost entire thin sections, by imaging first one half of a thin section, and then imaging the second half after physically rotating the sample in the SEM.

X-ray compositional maps were obtained by both EDS and WDS (Wavelength-Dispersive X-Ray Spectrometry) using the UNESP electron microprobe with accelerating voltage of $15 \mathrm{kV}$ and dwell times of 8-10 ms. Maps for $\mathrm{Al}, \mathrm{Mg}$, and Ti were used to identify plagioclase, pyroxene, and $\mathrm{Fe}-\mathrm{Ti}$ oxides, respectively.

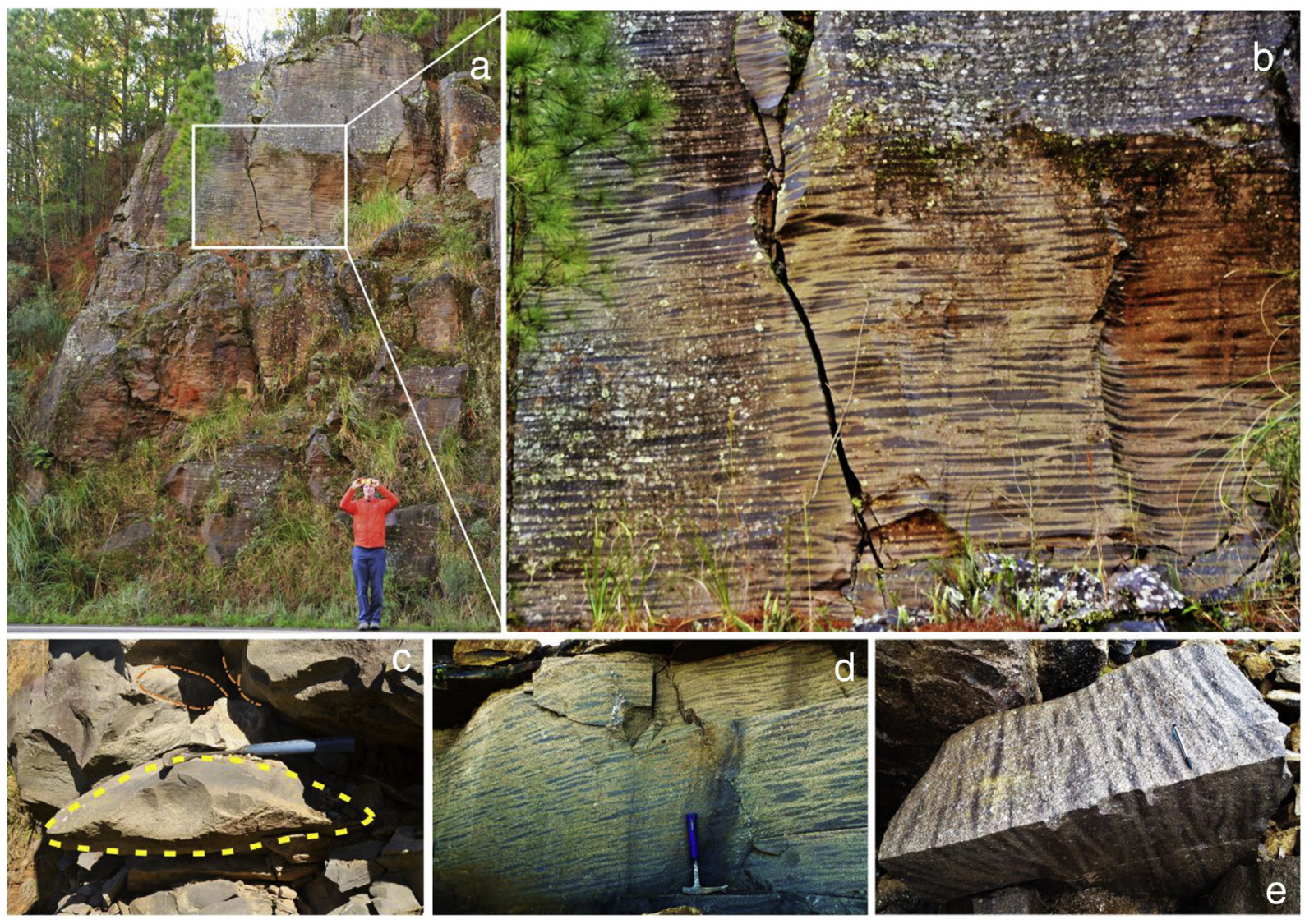

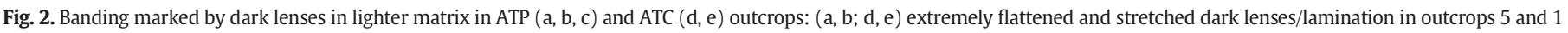
respectively (see location in Fig. 1); and in (c) one can note a loose thick dark 'lens' (yellow dashed line) and smaller lumps (orange dotted line) in outcrop 4. 
We used EBSD and X-ray maps to determine crystal size distributions. In the case of EBSD, touching crystals of the same phase can be readily separated due to the difference in crystallographic orientation. However, large sections of some crystals - particularly of plagioclase did not yield resolvable EBSD patterns, such that interiors had to be manually filled using routines available in the Tango software. In the case of X-ray maps, touching crystals were manually separated from each other using the free software ImageJ, with the aid of an optical microscope under which crystals were identified by differences in extinction angles and/or interference colour. The CSDSlice program (Morgan and Jerram, 2006) was used to determine 3D crystal shapes (aspect ratios), and stereological corrections were calculated using the CSDCorrections 1.50 program (Higgins, 2000) from results of measurements made in ImageJ (Abramoff et al., 2004).

We derived crystal size distributions for blobs and matrix using a combination of data from EBSD and X-ray maps. The EBSD maps were acquired at a higher resolution $(\sim 0.338$ pixels $/ \mu \mathrm{m})$ than the X-ray maps $(\sim 0.101$ pixels $/ \mu \mathrm{m})$. As a result, we were able to analyze a larger area with X-ray maps ( 2 thin sections) than with EBSD maps ( $<1$ thin section). As such, EBSD maps provide information on the smaller crystal populations, while the X-ray maps provide information on the larger crystals found in these rocks, with substantial overlap between the information gathered for intermediate crystal sizes. We thus combine information from both datasets to yield crystal size distributions over a wider range of crystal sizes (following Pamukcu \& Gualda, 2010). Importantly, there is good agreement between the results obtained for crystal sizes in which the two datasets overlap (see Section 4.2 of Results below).

\section{Results}

\subsection{Macroscopic and microscopic characteristics}

Field observations reveal the local presence of horizontally-to-subhorizontally oriented dark lens-shaped blobs, separated from each other by a matrix of lighter-colored material (Fig. 2), and no lithic fragments. Dark lenses are black to reddish brown, few to tens of centimeters thick and $>10 \mathrm{~cm}$ to more than a meter long (aspect ratios of 5:1 to 10:1). Locally, they can appear more elongated or extremely stretched/flattened ( $\geq 20: 1$ aspect ratios), particularly towards the base of outcrops, resulting in features that resemble flow-banding. Blobs are often bisected by sub-horizontal to slightly inclined fractures that can make identifying and measuring individual blobs difficult. Occasional detached blobs and 'lumps' can also be observed in some outcrops (Fig. 2c).

From a distance, contacts between dark lenses and matrix are easy to recognize and they appear sharp; however, close inspection reveals that they are diffuse and more difficult to trace in detail (Fig. 3). The matrix is characterized by white, spherical to irregular-shaped 'spots', which are smaller and less common in blobs. Rounded, oval, or drop-shaped vesicles from millimeters to centimeters in diameter, are partly or totally infilled with quartz and/or calcite and are more common in the matrix. In places, these vesicles are sub-parallel to the layering defined by the blobs.

Microscopically, the differences between blob and matrix are more subtle, partly due to the fact that much of the material is devitrified, obscuring original microscopic features. Both blobs and matrix are
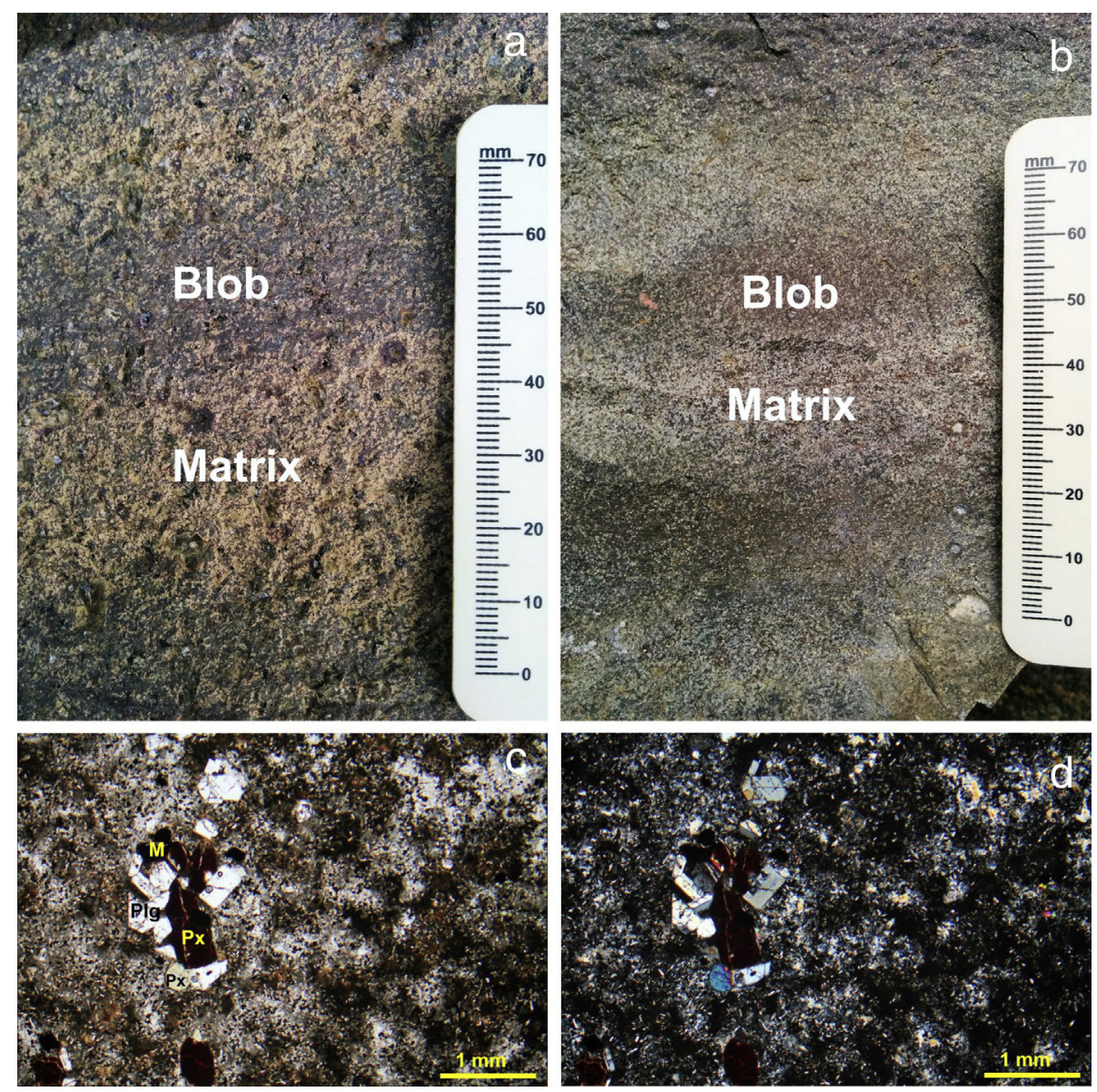

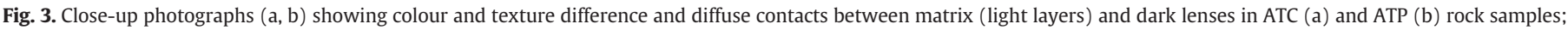

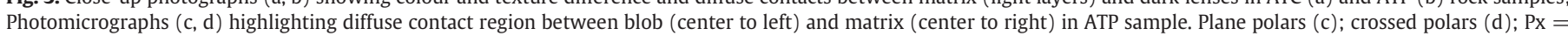
pyroxene; $\mathrm{Plg}=$ plagioclase; $\mathrm{M}=$ magnetite. 
characterized by a variable concentration of crystals $(\geq 100 \mu \mathrm{m})$ in a groundmass that is devitrified and locally silicified. Nonetheless, we see differences in groundmass textures and in crystal size distributions between blobs and matrix. Here the term "groundmass" refers both to the dark portion of the rock, called blob, and to the light portion, defined as the matrix in which the blobs lie. Under the optical microscope, the 'white spots' are composed of patches of brown or reddish brown glass (Fig. 4a-h). In some ATP samples, the 'spots' contain several tiny acicular opaque minerals and round quartz crystals. The groundmass of the blobs is often fully crystallized with quartz-feldspar microgranophyric intergrowths.

Mineral assemblages consist of plagioclase $>$ clinopyroxene (augite + pigeonite) $>$ Fe-Ti oxides $>$ apatite in ATC rocks and of plagioclase $>$ $>$ clinopyroxene (augite) + orthopyroxene $>\mathrm{Fe}-\mathrm{Ti}$ oxides in ATP rocks, with some ATP samples being aphyric (outcrops 5-6 in Fig. 1). Plagioclase crystals can reach $1 \mathrm{~cm}$ size in the ATC and $1 \mathrm{~mm}$ size in the ATP. Crystals are often euhedral, but they can also show rounded to irregular shapes or resorption textures, especially pyroxenes. Crystal clusters (glomerocrysts) are ubiquitous and analysis of the abundance of crystals reveals that blobs tend to be richer in crystals and crystal clusters than the matrix (Fig. 4a'-h').

Differences in groundmass texture between blobs and matrix are more evident in SEM images. Whereas blobs have a more homogeneous appearance due to the micro-cryptocrystalline quartz-feldspar intergrowth (microgranophyric texture), the matrix has a more patchy texture with darker patches surrounded by a lighter groundmass (microgranophyric texture) in back-scattered electron (BSE) images (Fig. 5a-d). Crystals smaller than $60 \mu \mathrm{m}$ size (microlites) include plagioclase, pyroxene (augite \pm pigeonite), $\mathrm{Fe}-\mathrm{Ti}$ oxides, and apatite. These crystals have shapes suggestive of very fast growth, with swallowtail ends, skeletal, dendritic or acicular shapes. It is also noteworthy that a higher concentration of pyroxene and- Fe-Ti oxides microlites exist within the quartz-feldspar growth areas and, therefore, there would be a slightly higher concentration of these microlites in blobs compared to matrix. Unfortunately this is difficult to observe for plagioclase due to recrystallization/devitrification. Dark gray patches in back-scattered electron (BSE) images (= dark brown under optical microscope) in the matrix have a fibrous or irregular texture (Fig. 5e-f), which shows compositions with a wide range in $\mathrm{FeO}\left(\sim 0.3-10\right.$ wt\%) and $\mathrm{K}_{2} \mathrm{O}(\sim 4-$ $12 \mathrm{wt} \%)$ contents, and narrower ranges in $\mathrm{SiO}_{2}(\sim 64-67 \mathrm{wt} \%)$ and $\mathrm{Al}_{2} \mathrm{O}_{3}$ ( 14-17 wt\%) contents. Under the optical microscope, dark brown patches in the matrix of some ATP thin sections, display a globular texture. In BSE images this globular texture is characterized by several small round-to-globular material or aggregates that are homogeneous in texture (Fig. 5f) and show $\mathrm{SiO}_{2}$ contents ranging from 78 to $>90 \mathrm{wt} \%$, suggesting silicification of the groundmass material. These differences in silica content in the groundmass textures are also reflected in bulk rock compositions. EDS maps show rhyolitic (ATC) to rhyodacitic-rhyolitic (ATP) compositions for blobs $\left(\sim 70 \mathrm{wt} \% \mathrm{SiO}_{2}\right)$ and trachytic (ATC) to dacitic (ATP) compositions for matrix ( 63-67 wt\% $\left.\mathrm{SiO}_{2}\right)$.

\subsection{CSD (crystal size distributions)}

As previously mentioned, there is good agreement between the CSD obtained from EBSD and X-ray maps, with the two datasets showing clear overlap for crystals of intermediate size (Fig. 6).
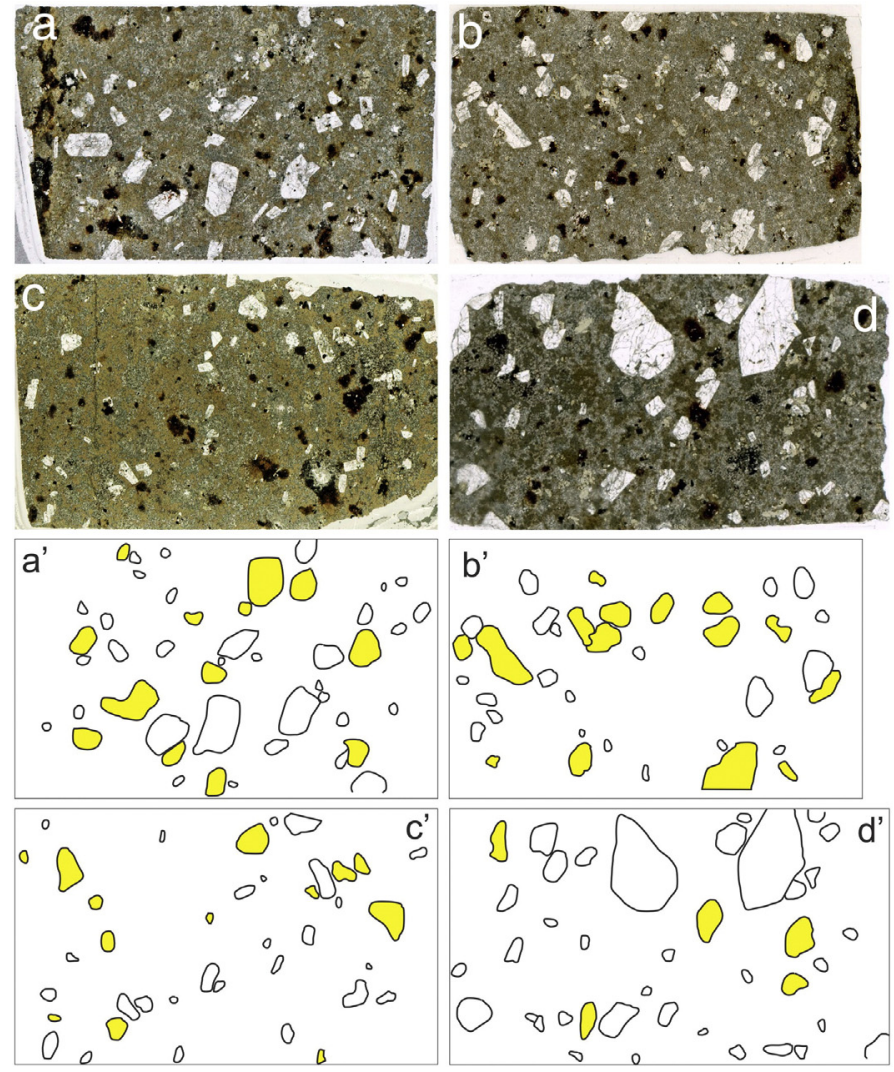
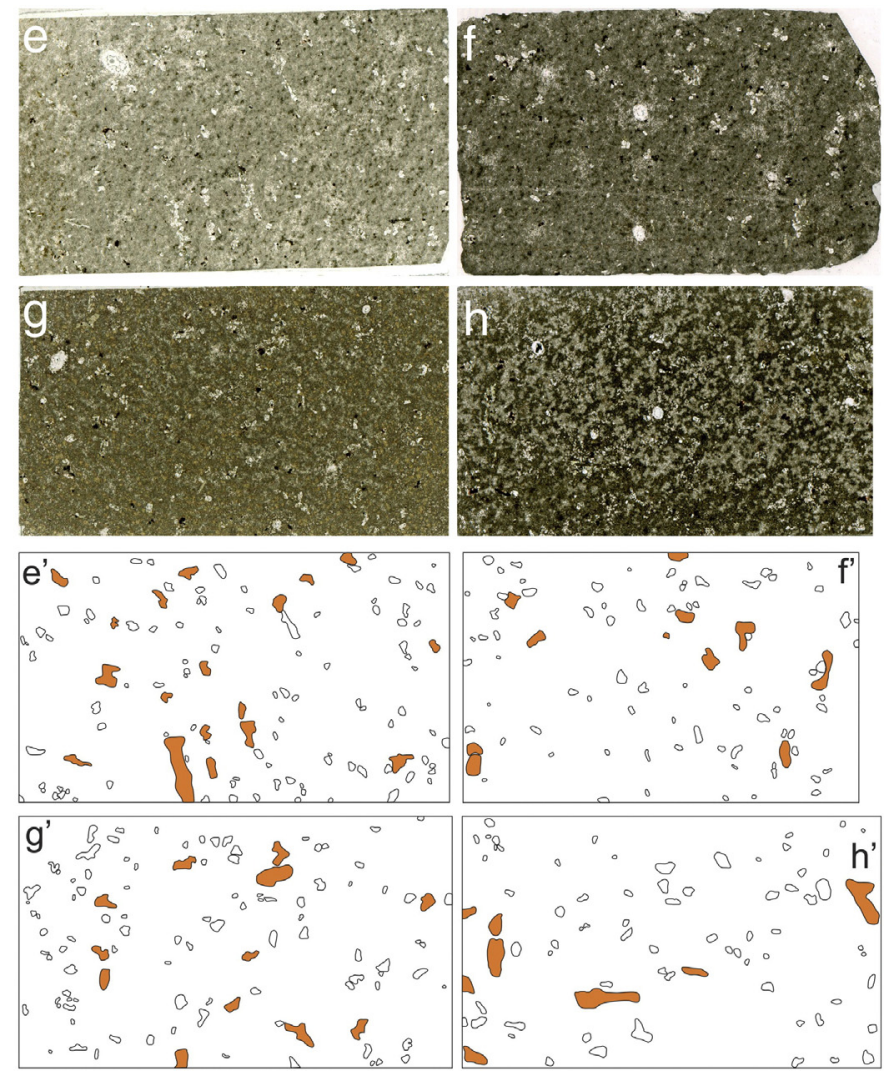

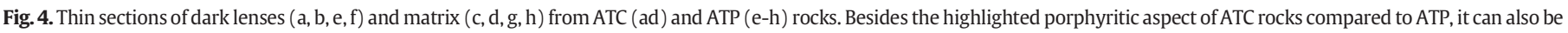

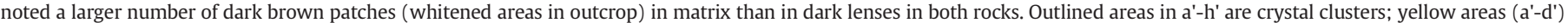

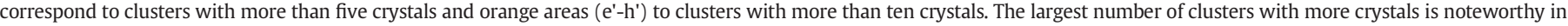

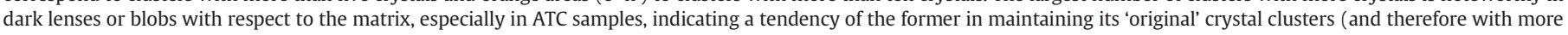
crystals). While the matrix would be less likely to maintain its 'original' crystal clusters due to a transport in a pyroclastic flow. Shorter lengths of the images have $\sim 24$ mm. 

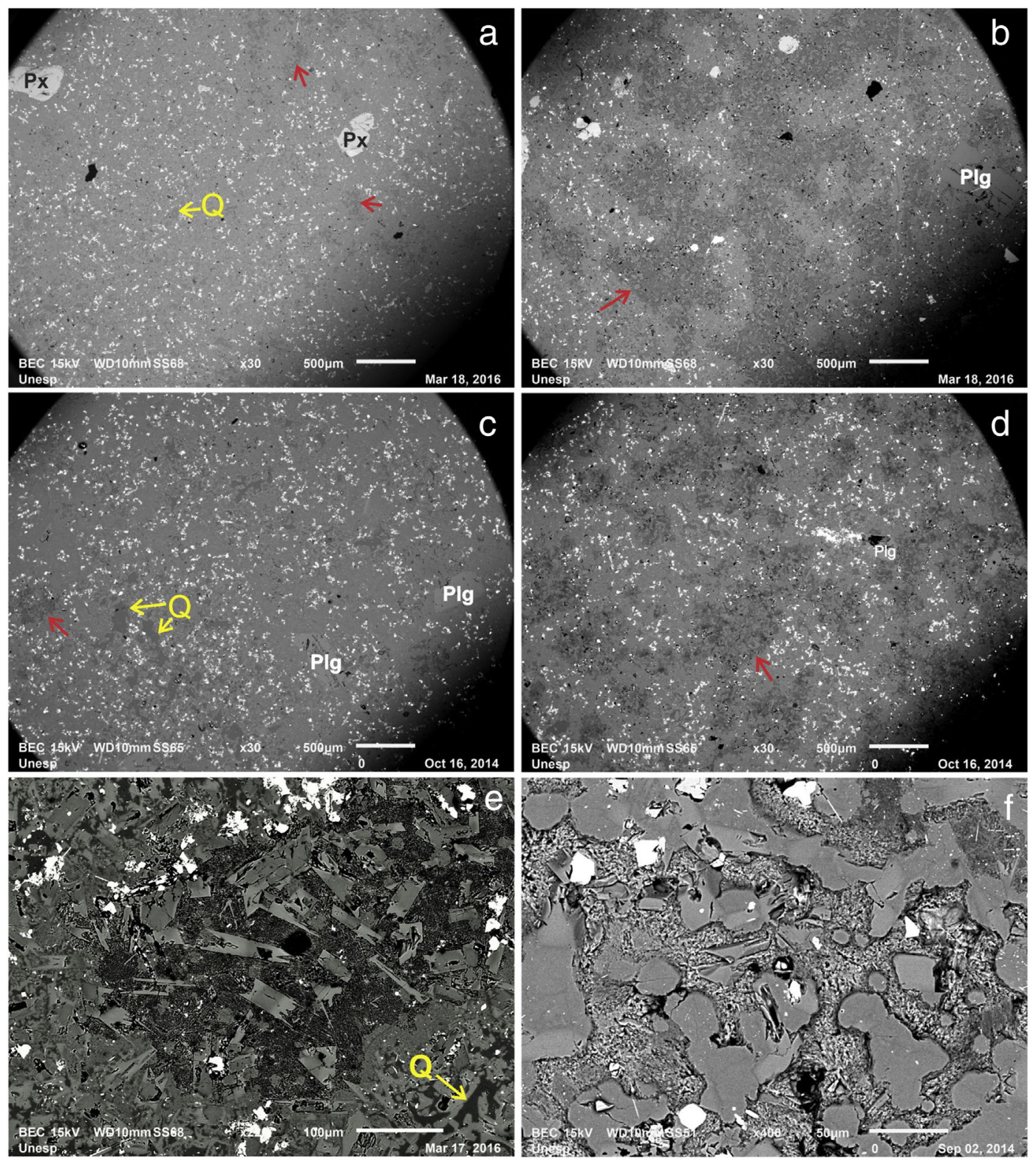

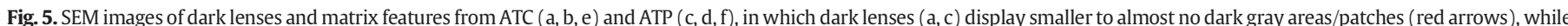

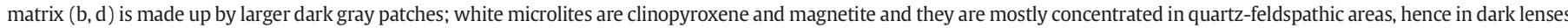

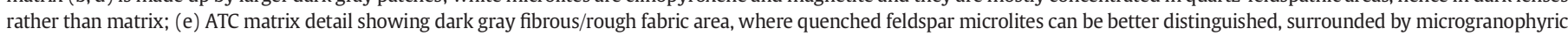

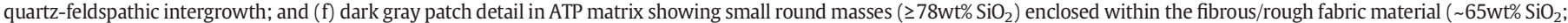
$4-12 \mathrm{wt} \% \mathrm{~K}_{2} \mathrm{O}$ ). Q = quartz; Px = pyroxene; Plg = plagioclase.

Blobs and matrix show very similar CSDs (Fig. 7a-d), with the main exception being the pyroxene CSD for ATP rocks (Fig. 7d). A kink can be identified in both plagioclase CSD for the blobs; the kink may be absent in the ATP matrix rock, or it may occur at a crystal size smaller than what we can quantify. The kinks are best seen in diagrams showing best-fit exponential curves to the blob data (Fig. 7e-f). The pyroxene CSD for the ATP matrix shows a concaveupward shape; however, the value for largest bin size controls the concave shape and, if it were excluded, an exponential CSD would be a very good approximation.

\section{Discussion}

\subsection{Origin of dark blobs, mode of emplacement, and welding}

Typical ignimbrites are characterized by the (+/-abundant) presence of pumice lapilli (e.g. Sparks et al., 1973; Fisher and Schmincke,
1984; Cas and Wright, 1987; Branney and Kokelaar, 2002). Further, ignimbrites can be incipiently to densely welded, where collapsed vesicular pumice fragments (fiamme) produce a characteristic strong foliation (eutaxitic texture) (Smith 1960a, b; Ross and Smith, 1961; Ragan and Sheridan, 1972; Cas and Wright, 1987). The features described here for dark blobs differ morphologically from typical fiamme or pumice, in that they have (1) a characteristic rounded nature with a more diffuse boundary with the matrix, (2) they are notably vesicle-poor and (3) they have a limited size range with no examples measured $<10 \mathrm{~cm}$ long and $5 \mathrm{~cm}$ wide. Being ancient deposits, the diffuse nature of the boundary between blobs and matrix has undoubtedly been enhanced by devitrification and chemical alteration processes; however, from our textural data (field and petrographic) there is no evidence that reveals an obvious gradational or diffuse alteration halo from the blobs into the matrix. In fact, our data supports a more patch-like and less systematic devitrification and silicification effect on both the matrix and the blobs. 


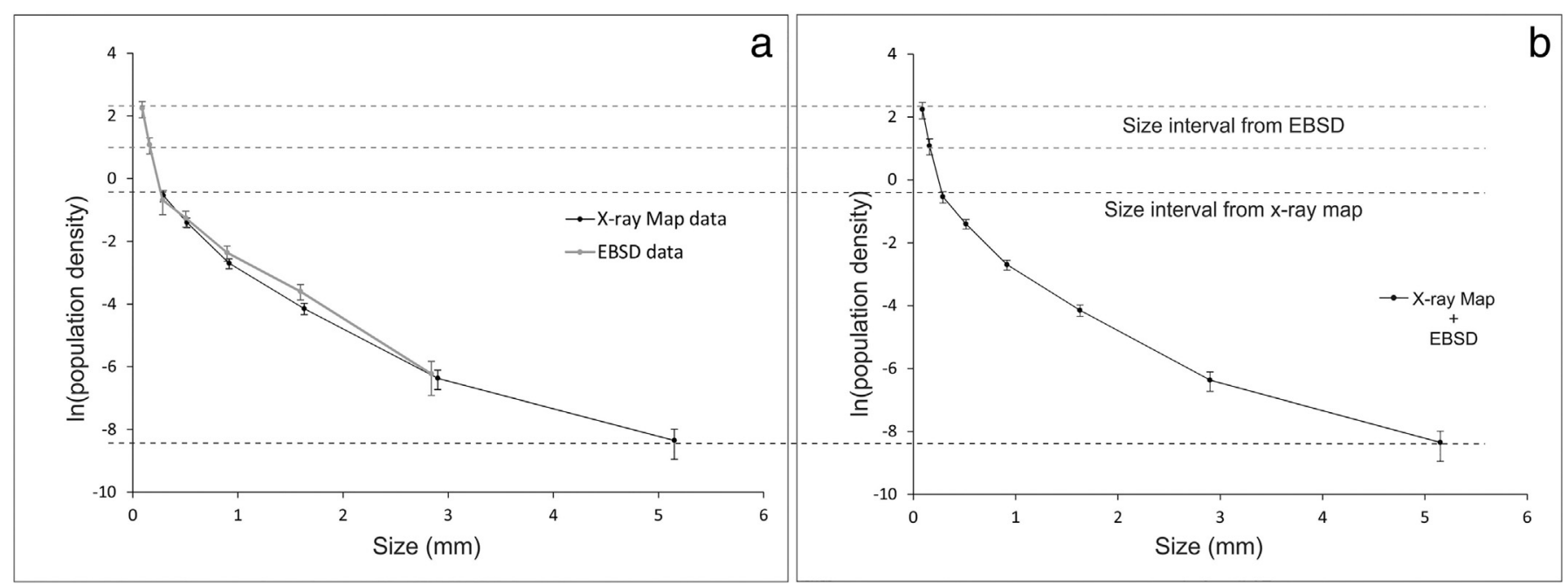

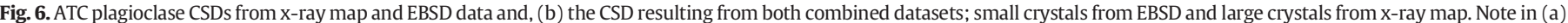
the close agreement between the datasets for intermediate crystal sizes.

The differences between blob and matrix textures are somewhat subtle, including those derived from CSD analysis. We note, nonetheless, that the blobs show a larger proportion of crystals forming the clusters compared to the matrix, which is consistent with blobs being subject to more limited disaggregation or 'fragmentation' than the matrix, as would be expected. Furthermore, the differences in the groundmass texture between blobs and matrix may indicate differences in volatile content and permeability, which has been reported in ignimbrite studies, where pumice probably contains more volatiles and are significantly less permeable than matrix, (e.g. Ross and Smith, 1961; Schmincke and Swanson, 1967; Ragan and Sheridan, 1972; Streck and Grunder, 1995; Sparks et al., 1999; Wright and Cashman, 2014). With low vesicularity blobs, this difference in permeability could be even more pronounced than it is with typical pumice. In ATP and ATC rocks, the poor permeability of the blob with respect to the matrix could have allowed efficient volatile (especially water) retention and thus led to a decrease in viscosity. This effect of retained water could be partially responsible for welding features in the ATP and ATC, including compaction and/or stretching of the blobs to form layers or laminations in the lower portions of the deposits (cf. effect on compaction rates of pumice in Ragan and Sheridan, 1972; Sparks et al., 1999). Another effect of water retention is an increase in crystallization/devitrification (cf. Ross and Smith, 1961; Schmincke and Swanson, 1967; Lofgren, 1970), which is evident in both ATP and ATC rocks. Heterogeneous patchy crystallization in the matrix also implies permeability anisotropy (Wright and Cashman, 2014), enabling efficient aqueous phase circulation through residual pore space and hence silica enriched and potassium impoverished zones, and vice versa, in the ATP and ATC rocks (cf. Scott, 1971). Matrix vesicles also reflect the activity of a vapor phase relative to crystallization (i.e. second-boiling - McArthur et al., 1998). In summary, as in pumice, blobs could have been completely compacted and/or crystallized whereas matrix remained with some residual porosity.

Other evidence for welding in the ATP and ATC rocks are the conspicuous fractures sub-parallel to and sometimes bisecting blobs. This structure has been described elsewhere, including in the densely welded Cougar Point Tuff (Bonnichsen and Citron, 1982). This may denote planes of weakness along the matrix-blob boundaries, and associated deformation during welding and compaction either during or post emplacement (or both) of the flow. Whether the extremely low aspect ratio blobs ( $\geq 20: 1)$ are flattened and/or stretched is beyond the scope of this study, and therefore the possibility of high-grade welding with associated post-depositional flow (rheomorphism; cf. Wolff and Wright, 1981; Bonnichsen and Citron, 1982; Henry et al., 1989; Branney et al.,
1992; Henry and Wolff, 1992; Andrews and Branney, 2011) cannot be ruled out as a possibility

Summarizing our results, we suggest that the lens-shaped blobs are barely-vesiculated juvenile magma fragments and are similar features to those described elsewhere, such as in the Fantale ignimbrite (Gibson, 1970), the Pagosa Peak lava-like ignimbrite (Bachmann et al., 2000), and andesitic spatters transported in pyroclastic flow on Santorini (Mellors and Sparks, 1991). The structural and textural features between blobs and matrix described above are more likely to have formed in an explosive pyroclastic flow-producing eruption than from an effusive lava flow- producing eruption. In this sense, the blobs would have resulted from fire-fountaining pyroclastic eruptions capable of generating pyroclastic flows, which are somewhat intermediate between typical ignimbrite-producing pyroclastic density currents and lavas. This would explain why many of the features observed in the ATP and ATC have proven to be elusive and have led to conflicting interpretations for the mode of emplacement of these deposits. Low vesicularity blobs indicate less pronounced vesiculation during magma ascent and significantly lower explosivity than more typical Plinian eruptions associated with silicic ignimbrite formation (e.g. Carey and Sigurdsson, 1989), as well does the lack of smaller juvenile blobs. This alternative emplacement mechanism also explains many of the microscopic characteristics we observe. Most importantly, it explains why we observe only subtle differences between blob and matrix textures, including the derived CSDs. Crystal clusters and the low abundance or absence of broken crystals, as evidenced by the euhedral shapes of plagioclase crystals, are typical of coherent lavas. However, the fragmentation process would not be as intense in fire-fountaining pyroclastic eruptions as in typical highly explosive ignimbrite-forming eruptions, and euhedral crystals and glomerophyric clusters could maintain their integrity.

We suggest that the possible eruption mechanism for the blob-bearing deposits of the ATP and ATC would not be much different from those mafic eruptions characterized by fire-fountains, in which pyroclasts are designated "spatters" and specific conditions, such as low magma viscosity and low pre-eruption volatile contents, are required (Wolff and Sumner, 2000; Sumner et al., 2005). Nevertheless, several examples of spatter deposits are also described from andesitic (Mellors and Sparks, 1991; Valentine et al., 2000; Allen, 2005) and felsic magmas (Duffield, 1990; Turbeville, 1992; Stevenson et al., 1993; Rosi et al., 1996; Sumner and Branney, 2002; Furukawa and Kamata, 2004; Self et al., 2008). In this context, the high temperatures ( $>900$ up to $>1000{ }^{\circ} \mathrm{C}$ $\left.{ }^{\circ} \mathrm{C}\right)$ and low volatile content $\left(\leq 2 \% \mathrm{H}_{2} \mathrm{O}\right)$ estimated for silicic magmas from PMP (Bellieni et al., 1986; Bellieni et al., 1988; Garland et al., 1995) support the idea of a low explosivity, fire-fountain eruption 

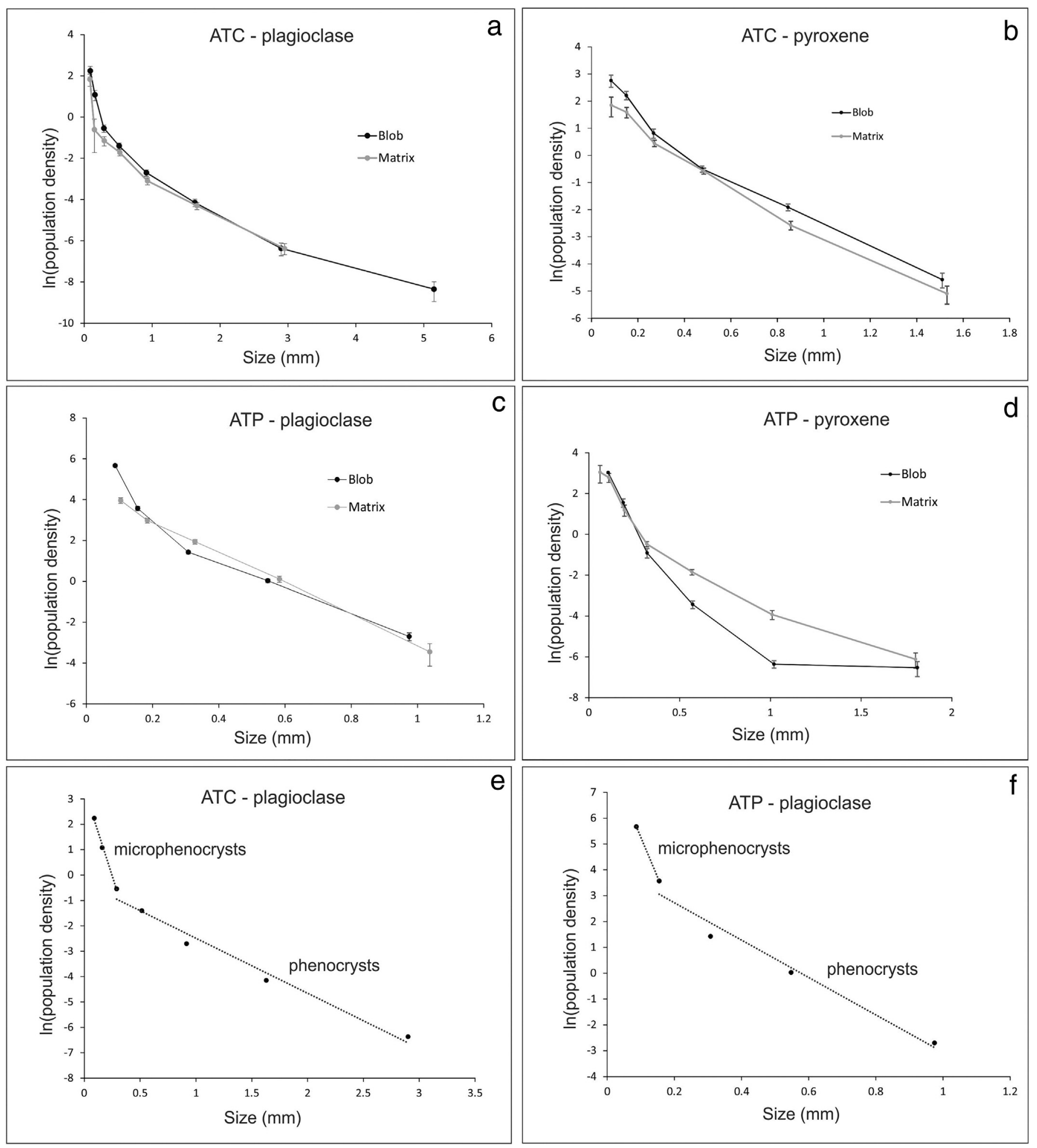

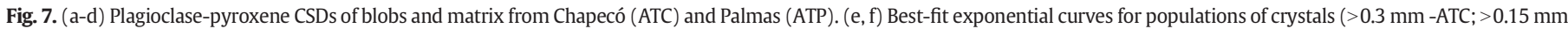
-ATP) and microphenocrysts (<0.3 mm -ATC; $<0.15 \mathrm{~mm}$-ATP) plagioclase crystals in blobs (see Table 1 ).

column (cf. Bachmann et al., 2000) feeding pyroclasts that are laterally transported and emplaced to form a densely welded ignimbrite. The high temperatures must have played a major role on the rheology of these materials, decreasing its viscosity and increasing the difference between emplacement temperature and glass transition temperature $\left(T_{g}\right)$, which, in turn, strongly influence the welding (Smith, 1960a,b; Quane and Russell, 2005; Russell and Quane, 2005). Furthermore, the fact that there has been no calderas identified in the PMP and the deposits are bereft of lithics necessitates further investigation into volcanic sources that are known to produce fire-fountain eruptions such as linear vent zones (fissures).

\subsection{Timescales of crystallization}

The kink in the CSDs of blobs seems to reflect two main different stages of crystallization represented by phenocrysts (pre-eruptive) 
Table 1

Parameters for best-fit exponential curves and estimated crystallization times for plagioclase crystal size distributions of blob samples from Chapecó (ATC) and Palmas (ATP).

\begin{tabular}{|c|c|c|c|c|c|c|c|}
\hline ATC & Slope $(S)$ & Intercept $\left(n^{\circ}\right)$ & $\mathrm{R}^{2}$ & $\mathrm{G}(\mathrm{mm} / \mathrm{s})$ & $\mathrm{T}(-1 / \mathrm{GS})$ & $\mathrm{L}_{\max }(\mathrm{mm})$ & $\mathrm{T}\left(\mathrm{L}_{\max } / \mathrm{G}\right)$ \\
\hline Phenocrysts & -2.17 & -0.32 & 0.98 & $\begin{array}{l}10^{-11} \\
10^{-10}\end{array}$ & $\begin{array}{l}1460 \\
146\end{array}$ & 10 & $\begin{array}{l}31,700 \\
3170\end{array}$ \\
\hline $\begin{array}{l}\text { Microphenocrysts } \\
\text { ATP }\end{array}$ & -13.69 & 3.39 & 0.99 & $10^{-10}$ & 23 & & \\
\hline Phenocrysts & -7.24 & 4.18 & 0.97 & $\begin{array}{l}10^{-11} \\
10^{-10}\end{array}$ & $\begin{array}{l}438 \\
44\end{array}$ & 1 & $\begin{array}{l}3170 \\
317\end{array}$ \\
\hline Microphenocrysts & -30.93 & 8.37 & 1 & $10^{-10}$ & 10 & & \\
\hline
\end{tabular}

$\mathrm{G}=$ growth rate for plagioclase from Cashman $(1988,1992)$.

$\mathrm{T}=$ residence time in years.

$\mathrm{L}_{\max }=$ the largest crystal size.

and microphenocrysts (syn-eruptive) as identified in many other systems (e.g. Cashman, 1988, 1992; Pamukcu et al., 2012; Pamukcu et al., 2013).

Timescales of crystallization can be derived from CSD if crystal growth rates can be constrained (Cashman and Marsh, 1988; Marsh, $1988,1998)$. The growth time of a crystal population is related to the slope of the CSD on a log-linear plot of population density vs crystal size (i.e., the exponent of the best-fit exponential curve). The slope corresponds to $-1 /(\mathrm{G} \tau)$, where $G$ is the linear growth rate and $\tau$ is the crystallization time. Alternatively, if the crystal growth rate is known, then a crystallization time can be calculated as the time for such crystal to grow: $\tau_{\max }=\mathrm{L}_{\max } / \mathrm{G}$, where $\mathrm{L}$ is crystal size. Plagioclase growth rates have been studied by Cashman $(1988,1992)$, with resulting growth rates of $10^{-14}$ and $10^{-13} \mathrm{~m} / \mathrm{s}$. These growth rates are consistent with (and somewhat slower than) quartz growth rates determined by Gualda et al. (2012) and Pamukcu et al. (2012, 2015), showing that crystal growth rates have a limited range of variability.

Utilizing these growth rates, we calculate plagioclase growth times using the CSD slopes for both large (phenocryst) and small (microphenocryst) crystal populations (Fig. 7e-f). Phenocryst populations yield timescales on the order of millennia, while microphenocryst populations yield timescales on the order of decades (Table 1). Uncertainties on these calculated times derive primarily from uncertainties in the used growth rates (Gualda et al., 2012). Given that we use conservative estimates for growth rates (see Pamukcu et al., 2015), we interpret these timescales as being maximum timescales associated with the growth of each crystal population.

Determination of maximum crystal sizes is required to calculate residence times based on $\mathrm{L}_{\max }$. ATC rocks include crystals as large as $10 \mathrm{~mm}$, while the largest crystals in Palmas rocks are closer to $1 \mathrm{~mm}$ in size. Thus, maximum growth times calculated using these sizes is on the order of a few thousand years (ATP) to a few tens of thousands of years (ATC), as detailed in Table 1. Again, uncertainties on growth rates are the main source of error in these calculations, and the use of conservative values for the growth rates renders these calculated values maximum estimates.

The CSD for plagioclase in the Chapecó sample can be interpreted as having an overabundance of large crystals, which leads to the concaveupward CSD. It is possible that these larger crystals are 'antecrysts', which did not crystallize from the melt in which they currently reside. The likely result of the presence of antecrysts is that maximum crystallization times would be overestimated, possibly explaining the discrepancy between estimates based on CSD slope and maximum crystal size, particularly for the Chapecó sample. However, magma mingling or mixing structures, which would explain such antecrysts, are seen neither in outcrops nor in thin sections. Nevertheless future research could better elucidate the origin of these crystals.

\section{Conclusions}

In this paper we present qualitative and quantitative structural and textural data, including crystal size distributions, for Chapecó-Palmas blobs and matrix from the Paraná Magmatic Province. The textures have been described from the outcrop scale down to the SEM scale. CSDs were obtained using a combination of EBSD and x-ray map datasets. Our results indicate these blobs correspond to poorly vesiculated magma fragments. These would have been transported in pyroclastic flows sourced from low-column pyroclastic fountains with relatively high discharge rates that led to the large volume and wide distribution of these deposits.

Crystal size distributions reveal the existence of two main crystal populations: one including crystals that form a log-linear size distribution with relatively shallow slopes, and thus represent the pre-eruptive growth of phenocrysts in a large magma body; and another including microphenocrysts, with much steeper log-linear size distributions and representing syn-eruptive nucleation and growth under significantly higher degrees of supersaturation. We also estimate the timescales of growth for both crystal populations. Using plagioclase growth rates from Cashman $(1988,1992)$ we estimate that the pre-eruptive crystal population grew on millennial timescales, whereas the syn-eruptive crystal population yielded timescales on the order of decades.

\section{Acknowledgements}

This study is part of $\mathrm{PhD}$ research by ACFL completed at the Universidade Estadual Paulista (UNESP), Instituto de Geociências e Ciências Exatas (IGCE). Funding and in-kind support were provided by National Council for Scientific and Technological Development (CNPq; PhD grant and support no. 484657/2011-9), Coordination for the Improvement of Higher Education Personnel (CAPES; PDSE-2998/13-0) and São Paulo Research Foundation (FAPESP; process no 11/10508-6). We acknowledge support from NSF grant EAR-1151337 to Gualda, and would like to thank K.F. Bull and C.P. De Campos for their helpful reviews that improved the manuscript considerably.

\section{References}

Abramoff, M.D., Magalhães, P.J., Ram, S.J., 2004. Image processing with ImageJ. Biophoton. Int. $11,36-42$.

Alberti, A., Piccirillo, E.M., Bellieni, G., Civetta, L., Comin-Chiaramonti, P., Morais, E.A.A., 1992. Mesozoic acid volcanics from southern Angola: petrology, Sr-Nd isotope characteristics, and correlation with the acid stratoid volcanic suítes of the Paraná Basin (south - eastern Brazil). Eur. J. Mineral. 4, 597-604.

Allen, S.R., 2005. Complex spatter- and pumice-rich pyroclastic deposits from an andesitic caldera-forming eruption: the Siwi pyroclastic sequence, Tanna. Vanuatu. Bull. Volcanol. 67, 27-41.

Andrews, G.D.M., Branney, M.J., Bonnichsen, B., 2008. Rhyolitic ignimbrites in the Rogerson Graben, southern Snake River plain volcanic province: volcanic stratigraphy, eruption history and basin evolution. Bull. Volcanol. 70, 269-291.

Andrews, G.D.M., Branney, M.J., 2011. Emplacement and rheomorphic deformation of a large rhyolitic ignimbrite: Grey's landing, southern Idaho. Geol. Soc. Am. Bull. 123, 725-743.

Bachmann, O., Dungan, M.A., Lipman, P.W., 2000. Voluminous lava-like precursor to a major ash-flow tuff: low-column pyroclastic eruption of the Pagosa Peak Dacite, San Juan volcanic field, Colorado. J. Volcanol. Geotherm. Res. 98, 153-171.

Bellieni, G., Brotzu, P., Comin-Chiaramonti, P., Ernesto, M., Ernesto, M., Melfi, A.J., Pacca, I.G., Piccirillo, E.M., 1984. Flood basalt to rhyolites suites in the southern Paraná plateau (Brazil): paleomagnetism, petrogenis and geodynamic implications. J. Petrol. $25,579-618$. 
Bellieni, G., Comin-Chiaramonti, P., Marques, L.S., Melfi, A.J., Nardy, A.J.R., Papatrechas, C. Piccirillo, E.M., Roisenberg, A., 1986. Petrogenetic aspects of acid and basaltic lavas from the Paraná plateau (Brazil): geological, mineralogical and petrochemical relationships. J. Petrol. 27, 915-944.

Bellieni, G., Piccirillo, E.M., Comin-Chiaramonti, P., Melfi, A.J., da Roit, P., 1988. MINERAL Chemistry of Continental Stratoid Volcanics and Related Intrusives from the Paraná Basin (Brazil). In: Piccirillo, E.M., Melfi, A.J. (Eds.), The Mesozoic Flood Volcanism of the Paraná Basin: Petrogenetic and Geophysical Aspects. 1988. Universidade de São Paulo, Instituto Astronômico e Geofísico, São Paulo 600 p. (ISBN 85-8504704-61).

Bonnichsen, B., 1982. Rhyolite lava flows in the Bruneau-Jarbidge eruptive Centre, southwestern Idaho. In: Bonnichsen, B., Breckenridge, R.M. (Eds.), Cenozoic Geology of Idaho. Idaho Bur. Mines. Geol. Bull. 26, pp. 283-320.

Bonnichsen, B., Citron, G.P., 1982. The Cougar Point Tuff, southwestern Idaho. In: Bonnichsen, B., Breckenridge, R.M. (Eds.), Cenozoic Geology of Idaho. Idaho Bur. Mines. Geol. Bull Vol. 26, pp. 255-281.

Bonnichsen, B., Kauffman, D.F., 1987. Physical features of rhyolite lava flows in the Snake River plain volcanic province, southwestern Idaho. Geol. Soc. Am. 212, 119-145 Special Publications.

Branney, M.J., Kokelaar, B.P., Mcconnell, B.J., 1992. The bad step tuff: a lava-like ignimbrite in a calc-alkaline piecemeal caldera, English Lake District. Bull. Volcanol. 54, 187-199.

Branney, M.J., Kokelaar, B.P., 1992. A reappraisal of ignimbrite emplacement: changes from particulate to non-particulate flow during progressive aggradation of highgrade ignimbrite. Bull. Volcanol. 54, 504-520.

Branney, M.J., Kokelaar, B.P., 2002. Pyroclastic density currents and the sedimentation of ignimbrites. Geol. Soc. Lond. Mem. 27, 1-152.

Branney, M.J., Bonnichsen, B., Andrews, G.D.M., Ellis, B., Barry, T.L., Mccurry, M., 2008. 'Snake River (SR)-type' volcanism at the Yellowstone hotspot track: distinctive products from unusual, high-temperature silicic super-eruptions. Bull. Volcanol. 70, 293-314.

Bryan, S.E., Ukstins-Peate, I., Peate, D.W., Self, S., Jerram, D.A., Mawby, M.R., Marsh, J.S., Miller, J.A., 2010. The largest volcanic eruptions on Earth. Earth-Sci. Rev. 102, 207-229.

Carey, S., Sigurdsson, H., 1989. The intensity of Plinian eruptions. Bull. Volcanol. 51, 28-40.

Cas, R.A.F., Wright, J.V., 1987. Volcanic Successions: Modern and Ancient. Alan and Unwin, London.

Cashman, K.V., Marsh, B.D., 1988. Crystal size distribution (CSD) in rocks and the kinetics and dynamics of crystallization II: Makaopuhi lava lake. Contrib. Mineral. Petrol. 99, 292-305.

Cashman, K.V., 1988. Crystallization of Mount St. Helens 1980-1986 dacite: a quantitative textural approach. Bull. Volcanol. 50, 194-209.

Cashman, K.V., 1992. Groundmass crystallization of Mount St. Helens dacite, 1980-1986: a tool for interpreting shallow magmatic processes. Contrib. Mineral. Petrol. 109, 431-449.

Duffield, W.A., 1990. Eruptive fountains of silicic magma and their possible effects on the tin content of fountain-fed lavas, Taylor Creek Rhyolite, New Mexico. Geol. Soc. Am. Spec. Pap. 246, 251-261.

Ekren, E.B., McIntyre, D.H., Bennett, E.H., 1984. High-temperature, large-volume, lava like ash-flow tuffs without calderas in southwestern Idaho. US Geol. Surv. Prof. Pap. 1272.

Ernesto, M., Raposo, M.I.B., Marques, L.S., Renne, P.R., Diogo, L.A., De Min, A., 1999. Paleomagnetism, geochemistry and ${ }^{40} \mathrm{Ar} /{ }^{39} \mathrm{Ar}$ dating of the north-eastern Paraná Magmatic Province: tectonic implications. J. Geodyn. 28, 321-340.

Ewart, A., Milner, S.C., Armstrong, R.A., Duncan, A.R., 1998. Etendeka volcanism of the Goboboseb Mountains and Messum igneous complex, Namibia. Part II: Voluminous quartz latite volcanism of the Awahab magma system. J. Petrol. 39, 227-253.

Fisher, R.V., Schmincke, H.U., 1984. Pyroclastic Rocks. Springer-Verlag, Berlin (472 pp).

Freundt, A., 1998. The formation of high-grade ignimbrites, I: experiments on high- and low-concentration transport systems containing sticky particles. Bull. Volcanol. 59, 414-435.

Furukawa, K., Kamata, H., 2004. Eruption and emplacement of the Yamakogawa Rhyolite in central Kyushu. Japan: a model for emplacement of rhyolitic spatter. Earth Planets Space. 56, 517-524.

Garland, F., Hawkesworth, C.J., Mantovani, M.S.M., 1995. Description and Petrogenesis of the Paraná rhyolites, southern Brazil. J. Petrol. 36 (5), 1193-1227.

Gibson, I.L., 1970. A pantelleritic welded ash flow tuff from the Ethiopian Rift Valley. Contrib. Mineral. Petrol. 13, 31-44.

Green, J.C., Fitz, T.J., 1993. Extensive felsic lavas and rheoignimbrites in the Keweenawan midcontinent rift plateau volcanics, Minnesota: petrographic and field recognition. J. Volcanol. Geotherm. Res. 54, 177-196.

Gualda, G.A.R., Pamukcu, A.S., Anderson Jr., A.T., Ghiorso, M.S., Sutton, S.R., Rivers, M.L., 2012. Timescales of quartz crystallization and the longevity of the Bishop giant magma body. PLoS One 7, e37492. http://dx.doi.org/10.1371/journal.pone.0037492.

Henry, C.D., Price, J.G., Rubin, J.N., Parker, D.F., Wolff, J.A., Self, S., Franklin, R., Barker, D.S., 1988. Widespread, lava-like silicic volcanic rocks of Trans-Pecos Texas. Geology 16, 509-512.

Henry, C.D., Price, J.G., Parker, D.F., Wolff, J.A., 1989. Mid-tertiary silicic alkalic magmatism of Trans-Pecos Texas: rheomorphic tufts and extensive silicic lavas. In: Chapin, C.E., Zidek, J. (Eds.), Field Excursions to Volcanic Terrains in the Western United States. I: Southern Rocky Mountain region. New Mex Bur. Mines. Min. Res. Mere Vol. 46, pp. 231-274.

Henry, C.D., Price, J.G., Rubin, J.N., Laubach, S.E., 1990. Case study of an extensive silicic lava: the Bracks rhyolite, Trans-Pecos Texas. J. Volcanol. Geotherm. Res. 43, 113-132.

Henry, C.D., Wolff, J.A., 1992. Distinguishing strongly rheomorphic tuffs from extensive silicic lavas. Bull. Volcanol. 54, 171-186.

Higgins, M.D., 2000. Measurement of crystal size distributions. Am. Mineral. 85 (9), 1105-1116.
Janasi, V.A., Freitas, V.A., Heaman, L.H., 2011. The onset of flood basalt volcanism, northern Paraná Basin, Brazil: a precise U-Pb baddeleyite/zircon age for a Chapecó-type dacite. Earth Planet Sci. Lett. 302, 147-153.

Lofgren, G., 1970. Experimental devitrification rate of rhyolite glass. Geol. Soc. Am. Bull. $81,553-560$.

Lima, E.F., Philipp, R.P., Rizzon, G.C., Waichel, B.L., Rossetti, L.M.M., 2012. Sucessões Vulcânicas e Modelo de Alimentação e Geração de Domos de Lava Ácidos da Formação Serra Geral na Região de São Marcos e Antonio Prado (RS). Geologia USP Série Científica. 12, pp. 49-64.

Luchetti, A.C.F., Nardy, A.J.R., Madeira, J.E.O., 2018. Silicic High-Grade to Extremely HighGrade Ignimbrites and Associated Deposits from Paraná Magmatic Province, Southern Brazil. J. Volcanol. Geotherm. Res. 355, 270-286.

Mahood, G.A., Hildreth, W., 1986. Geology of the peralkaline volcano at Pantelleria, straits of Sicily. Bull. Volcanol. 48, 143-172.

Marsh, B.D., 1988. Crystal size distribution (CSD) in rocks and the kinetics and dynamics of crystallization; I. Theory. Contrib. Mineral. Petrol. 99, 277-291.

Marsh, B.D., 1998. On the interpretation of crystal size distributions in magmatic systems J. Petrol. 39, 553-599.

Marsh, J.S., Ewart, A., Milner, S.C., Duncan, A.R., Mc Miller, R., 2001. The Etendeka Igneous Province: magma types and their stratigraphic distribution with implications for the evolution of the Parana-Etendeka flood basalt province. Bull. Volcanol. 62, 464-486.

McArthur, A.N., Cas, R.A.F., Orton, G.J., 1998. Distribution and significance of crystalline perlitic and vesicular textures in the Ordovician Garth Tuff (Wales). Bull. Volcanol. 60, 260-285.

Mellors, R.A., Sparks, R.S.J., 1991. Spatter-rich pyroclastic flow deposits on Santorini, Greece. Bull. Volcanol. 53 (327-342), 1991.

Milner, S.C., 1986. The geological and volcanological features of the quartz latites of the Etendeka formation. Communs. Geol. Surv. 2, 109-116 (SW Afr/Namibia).

Milner, S.C., Duncan, A.R., Ewart, A., 1992. Quartz latite rheoignimbrite flows of the Etendeka formation, north western Namibia. B. Volcanol. 54, 200-219.

Milner, S.C., Duncan, A.R., Whittingham, A.M., Ewart, A., 1995. Trans-Atlantic correlation of eruptive sequences and individual silicic volcanic units within the ParanaEtendeka igneous province. J. Volcanol. Geotherm. Res. 69, 137-157.

Mincato, R.L., Enzweiler, J., Schrank, A., 2003. Novas idades 39Ar/40Ar e implicações na metalogênese dos depósitos de sulfetos magmáticos de Ni-Cu-EPG na Província Ígnea Continental do Paraná. 9th Brazilian Congress of Geochemistry, Belém (Pará), Brazil, pp. 67-92 (November).

Morgan, D.J., Jerram, D.A., 2006. On estimating crystal shape for crystal size distribution analysis. J. Volcanol. Geotherm. Res. 154, 1-7.

Pamukcu, A.S., Gualda, G.A.R., 2010. Quantitative 3D petrography using x-ray tomography 2: combining information from various resolutions. Geosphere 6:775-781. http://dx doi.org/10.1130/GES00565.1.

Pamukcu, A.S., Gualda, G.A.R., Anderson, A.T., 2012. Crystallization stages of the Bishop tuff magma body recorded in crystal textures in pumice clasts. J. Petrol. 53: 589-609. http://dx.doi.org/10.1093/petrology/egr072.

Pamukcu, A.S., Carley, T.L., Gualda, G.A.R., Miller, C.F., Fergunson, C.A., 2013. The evolution of the peach spring Giant magma body: evidence from accessory Mineral textures and compositions, bulk pumice and glass geochemistry, and rhyolite-MELTS modeling. J. Petrol. 54:1109-1148. http://dx.doi.org/10.1093/petrology/egt007.

Pamukcu, A.S., Gualda, G.A.R., Ghiorso, M.S., Miller, C.F., McCracken, R.G., 2015. Phaseequilibrium geobarometers for silicic rocks based on rhyolite-MELTS. Part 3: Application to the Peach Spring Tuff (Arizona-California-Nevada, USA). Contrib. Mineral. Petrol. 169:33. http://dx.doi.org/10.1007/s00410-015-1122-y.

The Mesozoic Flood Volcanism of the Paraná Basin: Petrogenetic and Geophysical Aspects. In: Piccirillo, E.M., Melfi, A.J. (Eds.), Instituto Geofísico, Astronômico e Ciências Atmosféricas. Universidade de São Paulo, São Paulo, Brazil.

Pinto, V.M., Hartmann, L.S., Santos, J.O.S., Mcnaughton, N.J., Wildner, W., 2010. Zircon U$\mathrm{Pb}$ geochronology from the Paraná bimodal volcanic province support a brief eruptive cycle at 135 Ma. Chem. Geol. 28 (2), 93-102.

Polo, L.A., Janasi, V.A., 2014. Volcanic stratigraphy of intermediate to acidic rocks in southern Paraná Magmatic Province, Brazil. Geologia Usp Série Científica. 14, pp. 83-100

Quane, S.T., Russell, J.K., 2005. Welding: insights from high-temperature analogue experiments. J. Volcanol. Geotherm. Res. 142, 67-87.

Ragan, D.M., Sheridan, M.F., 1972. Compaction of the Bishop Tuff, California. Geol. Soc. Am. Bull. 83 (1), 95-106.

Renne, P.R., Ernesto, M., Pacca, I.G., Coe, R.S., Glen, J.M., Prévot, M., Perrin, M., 1992. The age of Parana flood volcanism, rifting of Gondwanaland, and the Jurassic-Cretaceous boundary. Science 258, 975-979.

Renne, P.R., Deckart, K., Ernesto, M., Féraud, G., Piccirillo, E.M., 1996a. Age of the Ponta Grossa dyke swarm (Brazil), and implications to Paraná flood volcanism. Earth Planet Sci. Lett. 144, 199-211.

Renne, P.R., Glen, J.M., Milner, S.C., Duncan, A.R., 1996b. Age of Etendeka flood volcanism and associated intrusions in southwestern Africa. Geology 24, 659-662.

Rosi, M., Vezzoli, L., Aleotti, P., De Censi, M., 1996. Interaction between caldera collapse and eruptive dynamics during the Campanian Ignimbrite eruption, Phlegraean Fields. Italy. Bull. Volcanol. 57, 541-554.

Ross, C.S., Smith, R.L., 1961. Ash-flow tuffs, their origin, geological relations and identification. US Geol. Surv. Prof. Pap. 366, 1-77.

Russell, J.K., Quane, S.T., 2005. Rheology of welding: inversion of field constraints. J. Volcanol. Geotherm. Res. 142, 173-191.

Schmincke, H.U., Swanson, D.A., 1967. Laminar viscous flowage structures in ash-flow tufts from Gran Canaria, Canary Islands. J. Geol. 75, 641-664.

Schmincke, H.U., 1969. Ignimbrite sequence on Gran Canaria. Bull. Volcanol. 35 1199-1219.

Scott, R.B., 1971. Alkali exchange during devitrification and hydration of glasses in ignimbrite cooling units. J. Geol. 79, 100-110. 
Self, S., de Silva, S.L., Cortés, J.A., 2008. Enigmatic clastogenic rhyolitic volcanism: The Corral de Coquena spatter ring, North Chile. J. Volcanol. Geotherm. Res. 177, $812-821$.

Smith, R.L., 1960a. Ash-flows - a review. Geol. Soc. Am. Bull. 71, 795-842.

Smith, R.L., 1960b. Zones and zonal variations in welded ash flows. US Geol. Surv. Prof. Pap. 354, 149-159.

Sparks, R., Self, S., Walker, G., 1973. Products of ignimbrite eruptions. Geology 1 (3), 115-118.

Sparks, R.S.J., Tait, S.R., Yanev, Y., 1999. Dense welding caused by volatile resorption. J. Geol. Soc. Lond. 156:217-225. http://dx.doi.org/10.1144/gsjgs.156.2.0217.

Stevenson, R.J., Briggs, R.M., Hodder, A.P.W., 1993. Emplacement history of a low-viscosity, fountain-fed pantelleritic lava flow. J. Volcanol. Geotherm. Res. 57, 39-56.

Streck, M.J., Grunder, A.L., 1995. Crystallization and welding variations in a widespread ig nimbrite sheet; the Rattlesnake Tuff, eastern Oregon, USA. Bull. Volcanol. 57 (3), 151-169.

Sumner, J.S., Branney, M.J., 2002. Emplacement and deformation of a heterogeneous, chemically zoned, rheomorphic and locally lava-like, peralkaline ignimbrite sheet: TL on Gran Canaria. J. Volcanol. Geotherm. Res. 115, 109-138.

Sumner, J.M., Blake, S., Matela, R.J., Wolff, J.A., 2005. Spatter. J. Volcanol. Geotherm. Res. $142,49-65$.

Thiede, D.S., Vasconcelos, P.M., 2010. Paraná flood basalts: rapid extrusion hypothesis confirmed by new ${ }^{40} \mathrm{Ar} /{ }^{39} \mathrm{Ar}$ results. Geology 38 (8), 747-750.
Turbeville, B.N., 1992. Tephra fountaining, rheomorphism, and spatter flow during emplacement of the Pitigliano Tufts, Latera caldera. Italy. J. Volcanol. Geotherm. Res. 53, 309-327.

Turner, S., Regelous, M., Kelley, S., Hawksworth, C., Mantovani, M.M.S., 1994. Magmatism and continental break-up in the South Atlantic: high precision ${ }^{40} \mathrm{Ar} /{ }^{39} \mathrm{Ar}$ geochronology. Earth Planet. Sci. Lett. 121, 333-348.

Valentine, G.A., Perry, F.V., WoldeGabriel, G., 2000. Field characteristics of deposits from spatter-rich pyroclastic density currents at Summer Coon volcano. Colorado. J. Volcanol. Geotherm. Res. 104, 187-199.

Waichel, B.L., Lima, E.F. De, Viana, A.R., Scherer, C.M., Bueno, G.V., Dutra, G., 2012. Stratigraphy and volcanic facies architecture of the Torres syncline, southern Brazil, and its role in understanding the Paraná-Etendeka continental flood Basalt Province. J. Volcanol. Geotherm. Res. 215-216, 74-82.

Whittingham, A.M., 1989. Geological features and geochemistry of the acid units of the Serra Geral Formation, south Brazil. Continental Magmatism, Santa Fé IAVCEI Abstracts: Santa Fé, New Mexico, p. 293.

Wolff, J.A., Wright, J.V., 1981. Rheomorphism of welded tuffs. J. Volcanol. Geotherm. Res. $10,13-34$.

Wolff, J.A., Sumner, J.M., 2000. Lava fountains and their products. In: Sigurdsson, H. (Ed.), Encyclopedia of Volcanoes. Academic Press, San Diego, Calif, pp. 321-329.

Wright, H.M., Cashman, K.V., 2014. Compaction and gas loss in welded pyroclastic deposits. GSA Bull. 126 (1/2):234-247. http://dx.doi.org/10.1130/B30668.1. 